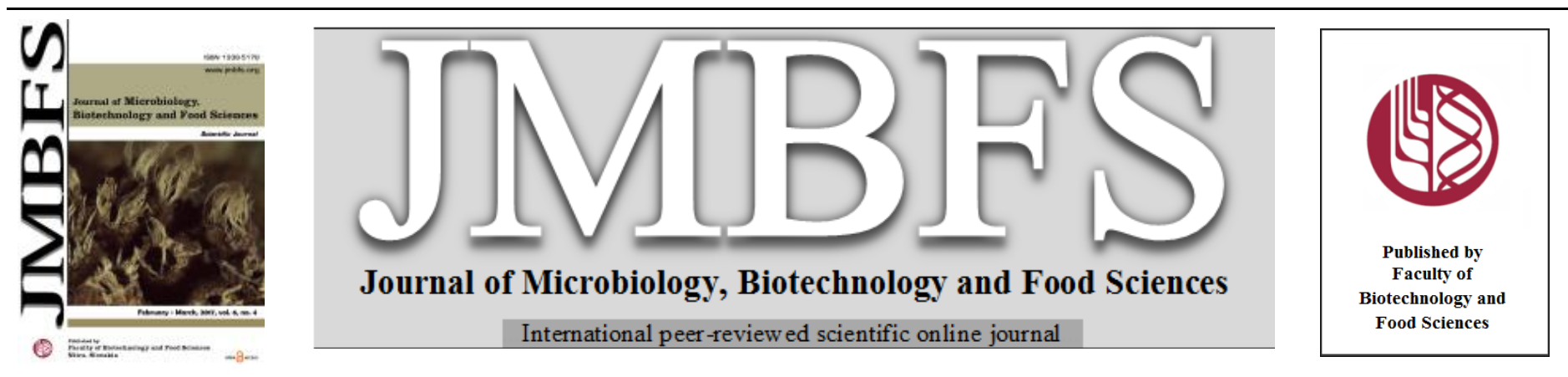

\title{
ISOLATION AND MOLECULAR CHARACTERIZATION OF THREE BACILLUS STRAINS FOR THEIR TOLERANCE AGAINST VARIOUS HEAVY METALS
}

\author{
Madhulika Chauhan $*^{I}$ and Manu Solanki ${ }^{1}$ \\ Address(es): Madhulika chauhan, \\ ${ }^{1}$ Department of Biotechnology, Manav Rachna International University, Faridabad, Haryana. India.
}

*Corresponding author: madhulika.chauhan20@gmail.com

doi: 10.15414/jmbfs.2017.6.4.1065-1069

\section{ARTICLE INFO}

Received 14. 6. 2016

Revised 6. 12. 2016

Accepted 11. 12. 2016

Published 1. 2. 2017

Regular article

open $\bigodot_{\text {ACCESS }}$

\begin{abstract}
Heavy metal contamination due to natural and anthropogenic sources is a global environmental threat which can produce harmful effects on human health when they are taken up in amounts that cannot be processed by the organism. Technologies involving microbial cells for metal removal and recovery may provide an alternative to conventional methods. In the present study, three cadmium resistant bacteria were isolated from soil collected from industrial area of Faridabad, Haryana, India. Screening of the bacterial isolates for metal resistance against $\mathrm{Cd}^{2+}, \mathrm{Ni}^{2+}, \mathrm{Hg}^{2+}, \mathrm{Cu}^{+2}$ and $\mathrm{Pb}^{2+}$ was done by determining the minimal inhibitory concentration ranging from $10 \mathrm{ppm}$ to 250ppm. Moreover these isolates showed a significant ability to remove 70 to $78 \%$ of cadmium. These isolates were identified as Bacillus sp.263ZY1 (MA5), Bacterium YC-LK-LKJ45 (MB5) and Bacillus subtilis strain DHXJ07(MC5) on the basis of 16S r-RNA gene sequencing. The ability of these microbes to tolerate high concentration of a range of heavy metals provides a scope of use of these bacterial strains for bioremediation of heavy metal from industrial effluent.
\end{abstract}

Keywords: Heavy metals, Bacillus strains, antibiotics sensitivity test, molecular characteristics, bioremediation

\section{INTRODUCTION}

The anthropogenic contamination of the environment with heavy metals is a global serious problem. Heavy metals like zinc, cadmium, copper, lead, nickel and mercury have been reported as the most toxic pollutants (Cameron, 1992) Although some heavy metals are essential trace elements, most can be at high concentration, toxic to all forms of life, including microbes, humans and animals. Among the list of heavy metals, the cadmium needs particular awareness because it is recognized as significant pollutant due to its high solubility and toxicity in the water. Cadmium gets released into the environment by various human activities such as mining, smelting, incineration of plastics and batteries, burning of fossil fuels etc (Tang $\boldsymbol{e t}$ al., 2006). It is toxic at very low exposure levels and has acute and chronic effects on health and environment. Acute exposure to cadmium fumes may cause flu like symptoms including chills, fever, and muscle ache. The long term exposure of these metals result in physical, muscular, neurological degenerative processes that cause Alzheimer's disease (brain disorder), Parkinson's disease (degenerative disease of the brain), muscular dystrophy (progressive skeletal muscle weakness), multiple sclerosis (a nervous system disease that affects brains and spinal cord).Cadmium may also combat with other metals such as zinc and selenium for enclosure into metallo-enzymes and it may compete with calcium for binding sites on regulatory proteins such as calmodulin (Hu et al., 1998). Being non degradable in nature, it stays in circulation once released into the environment. Removal of cadmium from effluents before they are discharged into the environment can be accomplished by processes such as, chemical precipitation, cementation, solvent extraction, reverse osmosis and ion exchange (Meena and Rajagopal, 2003). The physical or chemical methods of heavy metals remediation are neither suitable nor widely accepted for practical applications. A lot of emphasis is being paid to the use of bacteria to remediate heavy metals and it has emerged as one of the alternatives to physicochemical methods. Their use offers economic and ecological benefits, not only as a scientific novelty but also for its potential application in industry (Chen et al., 2005 and De et al., 2008). Some microorganisms have the resistance against the heavy metals and they can grow in the heavy metal rich environment also. To avoid cellular damage caused by metal ions, bacteria evolved mechanisms of metal tolerance. Recent studies shows that the strains (bacteria, yeast and fungi) isolated from contaminated sites possess excellent capability of metal scavenging (Malik, 2003). In the present study the efforts are directed towards the isolation of cadmium resistant bacteria that also shows resistance against other heavy metals and are potential candidates for the comprehensive treatment of metal-rich effluents.

\section{MATERIAL AND METHODS}

\section{Sample collection}

Soil samples were collected from five different sites of Faridabad industrial area, Haryana, India. All the samples were kept in clean sterile bags and stored at $4^{0} \mathrm{C}$.

\section{Isolation and identification of cadmium resistant bacteria}

The cadmium resistant bacteria were isolated by standard dilution method. The serially diluted soil samples were spread on the Luria-Bertani agar plates supplemented with $10 \mathrm{mM}$ of cadmium as cadmium nitrate. The plates were incubated at $30^{\circ} \mathrm{C}$ for 24 hours. The colonies that appeared on the medium supplemented with 10ppm cadmium were considered as cadmium resistant bacteria. Different colony characteristics such as colony color, elevation, shape, margin, texture were determined morphologically distinct colonies was picked and was purified by re-streaking on Luria Bertani medium plates. The isolates were stored on LB agar slants supplemented with $10 \mathrm{ppm}$ cadmium in a refrigerator and maintained by regular transfers.

\section{Growth kinetics of bacterial isolates in the presence of cadmium}

To study the growth kinetics of the isolates in the presence of heavy metals, LB broth and metal solution were separately autoclaved. The flasks were inoculated with $100 \mu$ l of overnight grown bacterial culture with different concentration of cadmium (10ppm and 20ppm) and were incubated at $30^{\circ} \mathrm{C}$ in rotator shaker. $\mathrm{LB}$ broth (without cadmium nitrate) inoculated with the culture served as control. An aliquot of culture was taken out in an oven sterilized tube, at regular intervals of $6,12,24,48,60,72,84,96,108$ and 120 hours and growth was monitored at regular intervals by measuring the optical density (OD) at $620 \mathrm{~nm}$.

\section{Determination of minimal inhibitory concentration (MIC)}

The minimum inhibitory concentration (MIC) of heavy metals was determined by the agar plate dilution method as described by Malik and Jaiswal (2000). Luria Bertani agar medium was prepared and amended with various amounts of heavy 
metals $(\mathrm{Cd}, \mathrm{Pb}, \mathrm{Ni}, \mathrm{Cu}$ and $\mathrm{Hg})$ to achieve the desired concentration of 10,20 , $40,60,80,100,120,140,160,180,200,220,240,260,280$, and 300ppm. Inoculum of bacterial strains was spread in the metal amended and control plates (without metal). The plates were incubated at $30^{\circ} \mathrm{C}$ for 48 hours. The MIC was defined as the lowest concentration of the metals that inhibits the visible growth (number of colonies) of the organisms.

\section{Antibiotic susceptibility}

Selected bacterial isolates were tested for susceptibility to 12 different antibiotics(Axiom Laboratories) by the disc diffusion method on Muller Hilton agar $(2 \mathrm{~g}$ beef extract, $17.50 \mathrm{~g}$ Acid hydrolysate of casein, $1.5 \mathrm{~g}$ starch, $17 \mathrm{~g}$ Agar) plates. The antibiotics tested were: penicillin $(20 \mu \mathrm{g})$, Co-trimoxazole $(25$ $\mu \mathrm{g})$, cephalexin $(30 \mu \mathrm{g})$, tetracycline $(30 \mu \mathrm{g})$, cefotaxime $(30 \mu \mathrm{g})$, ciprofloxacin $(5 \mu \mathrm{g})$, Levofloxacin $(5 \mu \mathrm{g})$, linezolid $(30 \mu \mathrm{g})$, cloxacillin $(30 \mu \mathrm{g})$, roxithromycin $(5 \mu \mathrm{g})$, Lincomycin $(2 \mu \mathrm{g})$ and gentamicin $(10 \mu \mathrm{g})$. The antibiotics discs were placed on the plates previously seeded with cell suspension. The plates were incubated at $300 \mathrm{C}$ for $72 \mathrm{~h}$ and observed for zones of inhibition.

\section{Isolation of plasmid and electrophoresis}

The bacterial isolates were screened for the presence of plasmid DNA using the alkaline lysis method (Sambrook et al., 1989). Plasmid profiles were determined on $0.8 \%$ agarose gels prepared in Tris-Borate-EDTA buffer, $\mathrm{pH}$ 8.0, stained with ethidium bromide and documented with an Imagemaster digital camera and associated annotation software (Syngene, USA).

\section{Cadmium accumulation and removal assay by bacterial isolates}

Selected isolates were grown in LB medium supplemented with $100 \mu \mathrm{g} / \mathrm{m}$ cadmium as cadmium nitrate. The flasks were incubated on a shaker for 120 hours at $30^{\circ} \mathrm{C}$.Cells were harvested at 24 and $48 \mathrm{~h}$ of incubation by centrifugation (1100xg for 10 minutes at $4^{0} \mathrm{C}$ ). Bacterial cell residue was dissolved in $1 \mathrm{ml} 95 \%$ nitric acid mixed well by vortexing and diluted to $10 \mathrm{ml}$ with sterile DDW. Blanks were treated in the same way and analyzed by atomic absorption spectrometry. Cadmium was measured from the supernatant by the atomic absorption spectrometry. Percentage of $\mathrm{Cd}$ removal by the bacterial cells from the culture was calculated by taking difference between the initial metal content in the culture media and at the time of sampling (Sinha and Mukharjee, 2009).

\section{S rRNA sequence and phylogenetic analysis}

The metal resistant isolates were identified using 16s rDNA sequencing. Genomic DNA was extracted from the isolates using CTAB method (Ausubel $\boldsymbol{e}$ al., 1987) and the quality of the product was checked on $0.8 \%$ TBE Agarose gel. PCR amplification of $16 \mathrm{~S}$ rDNA with forward: 5, AGHGTBTGHTCMTGNCTCAS-3' and reverse: ${ }^{2}$, TRCGGYTMCCTTGTWHCGACTH-3' primers was carried out using 10ng of genomic DNA. The amplification reactions were performed in a $25 \mu \mathrm{l}$ volume. The standardized conditions for PCR based amplification for each $100 \mu 1$ of reaction mixture were: PCR buffer containing $15 \mathrm{mM} \mathrm{MgCl}_{2}$ (10x); 100-200 ng of pure genomic DNA, $1000 \mathrm{pM}$ of each primer, $25 \mu \mathrm{M}$ each of the dNTP's $(100 \mu \mathrm{m}$ in a mixture of dNTPs) and 3 units of Taq polymerase. The volume was made up with milli $Q$ water The reaction mixtures were incubated in a thermal cycler (ABI2720, Applied Biosystems) at $94^{\circ} \mathrm{C}$ for $5 \mathrm{~min}$ and then subjected to 35 cycles consisting of $94^{\circ} \mathrm{C}$ for $30 \mathrm{~s}, 55^{\circ} \mathrm{C}$ for $30 \mathrm{~s}$ and $72^{\circ} \mathrm{C}$ for $1 \mathrm{~min} 15 \mathrm{sec}$. Finally the mixtures were incubated at $72^{\circ} \mathrm{C}$ for $15 \mathrm{~min}$. The amplified product was resolved on $2.0 \%$ agarose gel with a constant voltage of $20 \mathrm{~V}$ for $1 \mathrm{~h}$ followed by $50 \mathrm{~V}$ for $3 \mathrm{~h}$. The gels were stained with ethidium bromide and visualized under gel documentation. Sanger sequences were generated using an ABI 3130 Genetic Analyser (Applied biosystem). Phylogenetic analysis was carried out using distance-based phylogeny reconstruction method called "weighted neighbor joining," or "Weighbor" (Bruno et al., 2000). The trees were then validated by bootstrap.

\section{RESULTS AND DISCUSSION}

A total of 30 bacterial isolates were initially isolated from soil samples on LB agar plates. Out of thirty, three bacterial isolates were selected on the basis of cultural characteristics such as color, form, margin, and elevation and named as MA5, MB5 and MC5. A detailed result for colonial morphology, biochemical and physiology characteristics has been given in Table 1.
Table 1 Morphological, biochemical and physiological characteristics of selected isolates

\begin{tabular}{|c|c|c|c|}
\hline \multirow{2}{*}{$\begin{array}{l}\text { Morphological } \\
\text { observation }\end{array}$} & \multicolumn{3}{|c|}{ Bacterial isolates } \\
\hline & MA5 & MB5 & MC5 \\
\hline Colony color & Off white & White & Milky white \\
\hline Gram reaction & Positive & Positive & Positive \\
\hline Cell shape & Rod & Rod & Rod \\
\hline Spore formation & positive & Positive & Positive \\
\hline Elevation & Flat & Flat & Flat \\
\hline Margin & lobate & lobate & lobate \\
\hline \multicolumn{4}{|l|}{ Biochemical tests } \\
\hline Catalase test & Positive & Positive & Positive \\
\hline Starch hydrolysis & Positive & Positive & Positive \\
\hline $\mathrm{H}_{2} \mathrm{~S}$ production & Negative & Positive & Negative \\
\hline
\end{tabular}

Growth kinetics of Bacterial strains in the presence of different concentration of cadmium

Growth kinetics of each of the isolates was studied in the presence of cadmium Results showed that growth was not considerably affected in the presence of cadmium indicating their resistance to cadmium. MB5 showed maximum growth after 120 hours in the presence of cadmium (Figure1).
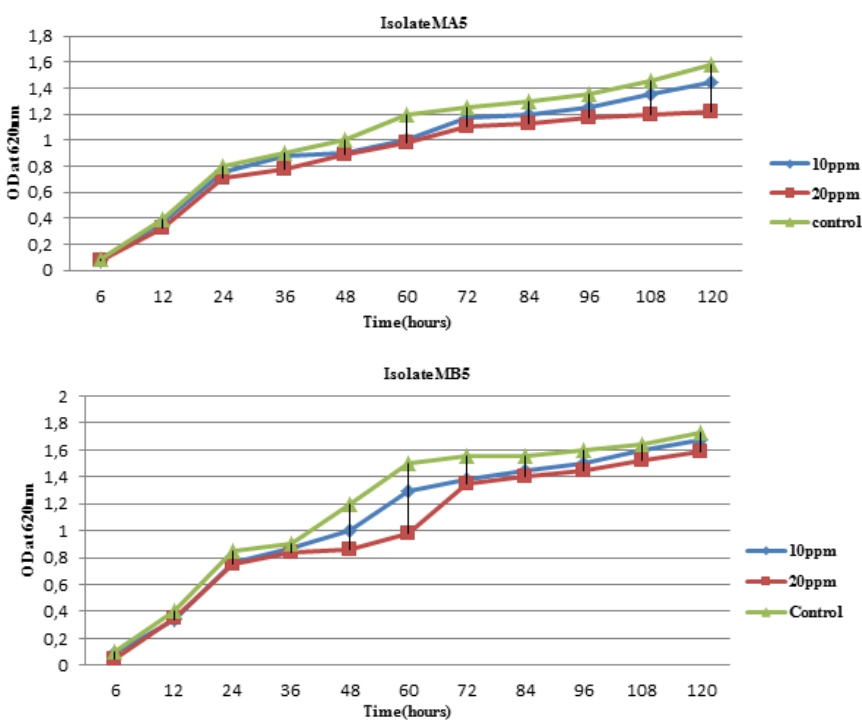

solate MC5

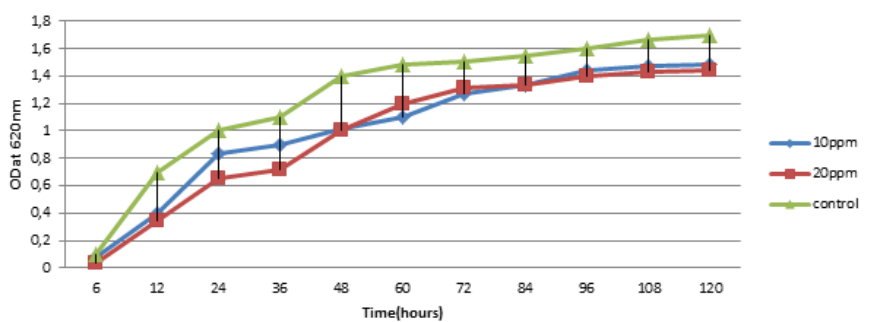

Figure 1 Growth curves of Cadmium resistance bacterial isolates (MA5, MB5 and MC5) in LB medium containing 10ppm and 20ppm concentration.

\section{Minimal Inhibitory Concentration (MIC) of heavy metals}

The isolates showed very high degree of resistance to all heavy metals. Minimum inhibitory concentration of $\mathrm{Cd}$ for all the isolates was $160 \mathrm{ppm}$. MIC of $\mathrm{Hg}$ was $120 \mathrm{ppm}$ for MC5, while for the other strains it was 100ppm. MIC of Pb was 180 for all strains. Isolates MA5 and MB5 (100-200ppm) showed to same order of metals toxicity. Among all three bacterial isolates, MC5 showed a very high degree of resistance to heavy metals. The order of heavy metals toxicity towards MC5 was $\mathrm{Hg}>\mathrm{Pb}=\mathrm{Cu}>\mathrm{Cd}>\mathrm{Ni}$ 
Table 2 Minimal inhibitory concentrations (MIC) of various heavy metals to the isolates

\begin{tabular}{lccccc}
\hline \multirow{2}{*}{$\begin{array}{l}\text { Bacterial } \\
\text { isolates }\end{array}$} & \multicolumn{5}{c}{ Heavy metals(ppm) } \\
\cline { 2 - 6 } & Cadmium & Lead & Mercury & Copper & Nickel \\
\hline MA5 & 160 & 180 & 100 & 180 & 200 \\
MB5 & 160 & 180 & 100 & 180 & 200 \\
MC5 & 160 & 180 & 120 & 180 & 200 \\
\hline
\end{tabular}

Antimicrobial susceptibility and Plasmid profile

In order to determine the resistance to antibiotics, the reactions to 12 antibiotics were examined by the disc diffusion method. After incubating for $72 \mathrm{~h}$, the appearance of colonies on plates with antibiotics disc was observed. Depending on the zone of inhibition results were interpreted as susceptible, intermediary susceptible and resistant, as recommended by CLSI. MA5 showed resistance against cefotaxime and levofloxacin. MB5 was resistant to ampicilin, cloxacillin, co-trimoxazole, cephalxin, and cefataxime and sensitive to other antibiotics. MC5 was found resistant to cefotaxime and sensitive to all the other 11 antibiotics.

Table 3 Antibiotic sensitivity for bacterial strains (MA5, MB5, MC5)

\begin{tabular}{lccc}
\multirow{2}{*}{ Antibiotics } & \multicolumn{3}{c}{ Bacterial isolates } \\
\cline { 2 - 4 } & MA5 & MB5 & MC5 \\
\hline Ampicillin(20mcg) & S & R & I \\
Co-Trimoxazole(25mcg) & I & R & I \\
Cephalexin(30mcg) & I & R & I \\
Tetracycline(30mcg) & I & I & I \\
Cefotaxime(30mcg) & R & R & R \\
Lincomycin(2mcg) & R & I & I \\
Ciprofloxacin(5mcg) & S & S & I \\
Levofloxacin(5mcg) & S & S & S \\
Linezolid(30mcg) & S & S & S \\
Cloxacillin(5mcg) & I & R & S \\
Gentamycin(10mcg) & S & I & S \\
Roxithromycin(15mcg) & S & S & S \\
\hline
\end{tabular}

R-resistant, I-Intermediate resistance, S-sensitive

\section{Isolation of plasmid and electrophoresis}

All the three bacterial isolates were screened for the presence of plasmid. Plasmid profile (Figure 3 ) indicates the presence of a mega plasmid (more than 10,000 $\mathrm{bp})$.

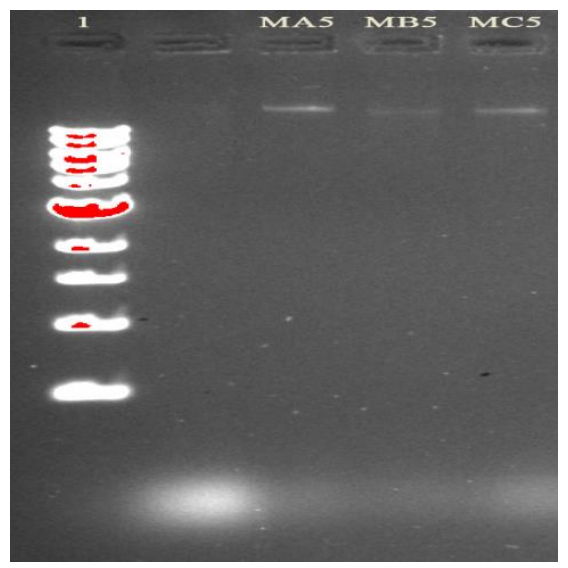

Figure 3 Plasmid DNA was extracted and separated by agarose ge electrophoresis (DNA ladder in lane 1); MA5 is loaded in lane3, MB5 in lane 4, MC5 in lane5.

\section{Cadmium removal assay}

The isolates were examined for their ability to remediate the cadmium from aqueous solution. It was observed that the isolates could remove upto $78 \%$ of the Cd from medium amended with 100ppm cadmium (Tab 4). Isolate MA5 showed maximum removal of $\mathrm{Cd}(74 \%$ and $78 \%)$, after 24 and 48hours of incubation respectively and isolate MB5 could efficiently remove $70 \%$ and $72 \%$ of $\mathrm{Cd}$ after 24 and 48hours of incubation respectively. In case of MC5, the concentration of Cd was reduced to $74 \%$ from an initial concentration of 100ppm in 48 hours.
Table 4 Percentage removal of cadmium by bacterial isolates from medium with initial concentration of $100 \mathrm{ppm}$ cadmium after 24 and 48hours of incubation at $30^{\circ} \mathrm{C}$.

\begin{tabular}{lcc}
\hline \multirow{2}{*}{ Bacterial isolates } & \multicolumn{2}{c}{ Cadmium removal (\%) } \\
\cline { 2 - 3 } & After $\mathbf{2 4 h}$ & After $\mathbf{4 8 h}$ \\
\hline MA5 & 74 & 78 \\
MB5 & 70 & 72 \\
MC5 & 72 & 74 \\
\hline
\end{tabular}

16S r-RNA sequence and phylogenetic analysis

The genomic DNA (Figure 4) was isolated and amplified with 16S rRNA specific primers. The length of the amplified DNA fragments is about 1.5bp (Figure 5) Sequence analysis of the DNA fragments was performed and compared against the GenBank database using the NCBI Blast program. Selected sequences of other microorganisms with greatest similarity to the 16SrRNA sequences of bacterial isolates were extracted from the nucleotide sequence databases and deposited in GenBank under accession number of KU513823, KU513824, KU513825 for MA5, MB5and MC5 respectively (Tab 5). These 16S rRNA sequences were aligned by MUSLE for construction of phylogenetic tree using neighbor joining method (Saitou and Nei 1987). Evolutionary analyses were conducted in MEGA7 (Kumar et al., 2015).

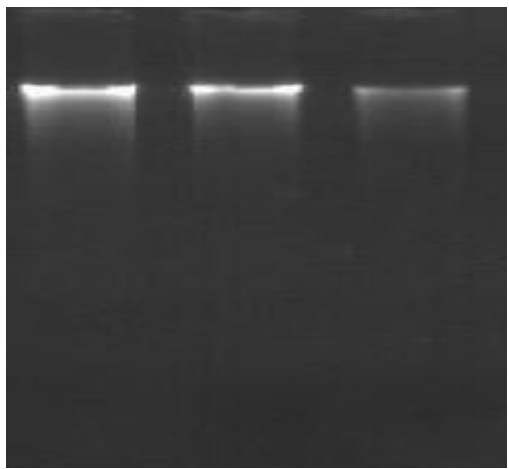

Figure 4 Extraction of Genomic DNA from Bacterial sample using the Bacterial Genomic DNA Isolation Kit (RKN15).

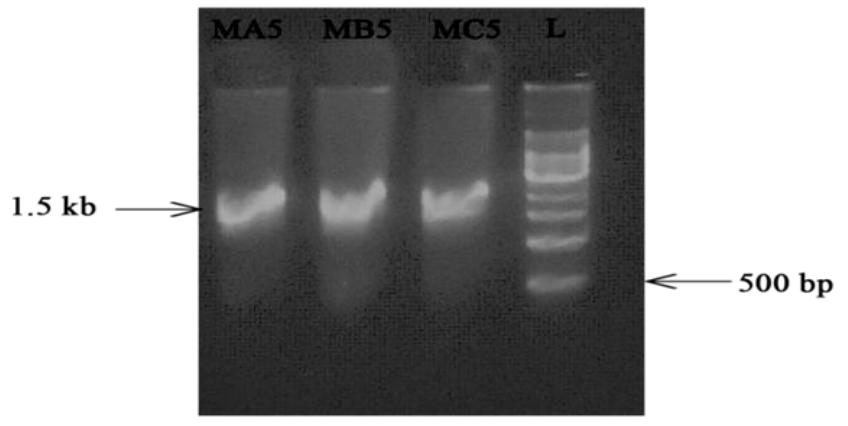

Figure 5 PCR amplification of 16s rDNA fragment from Bacterial sample. The size of PCR amplified product is $\sim 1.5 \mathrm{~kb}$

Table 5 Molecular identification of the isolates based on partial 16S rDNA analysis

\begin{tabular}{lccc}
\hline $\begin{array}{l}\text { Bacterial } \\
\text { isolates }\end{array}$ & $\begin{array}{c}\text { Bacterial strain showing } \\
\text { maximum homology }\end{array}$ & $\begin{array}{c}\text { Identity } \\
\mathbf{( \% )}\end{array}$ & $\begin{array}{c}\text { GenBank } \\
\text { accession No. }\end{array}$ \\
\cline { 2 - 4 } MA5 & Bacillus sp. 263ZY1 & $99 \%$ & KU513823 \\
MB5 & Bacterium YC-LK-LKJ45 & $99 \%$ & KU513824 \\
MC5 & Bacillus subtilis strain DHXJ07 & $99 \%$ & KU513825 \\
\hline
\end{tabular}




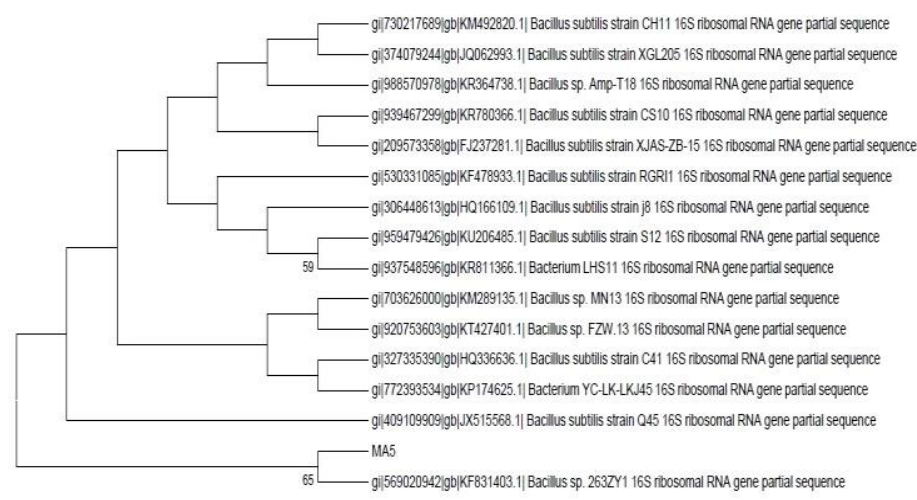

(a)

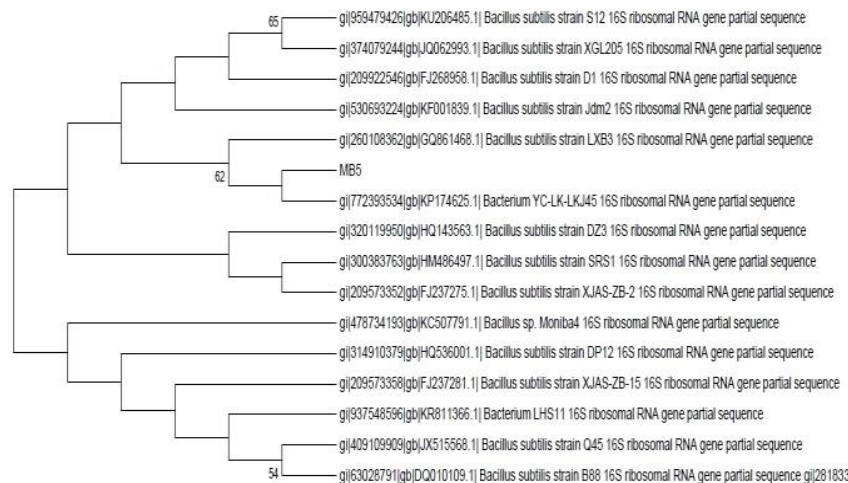

(b)

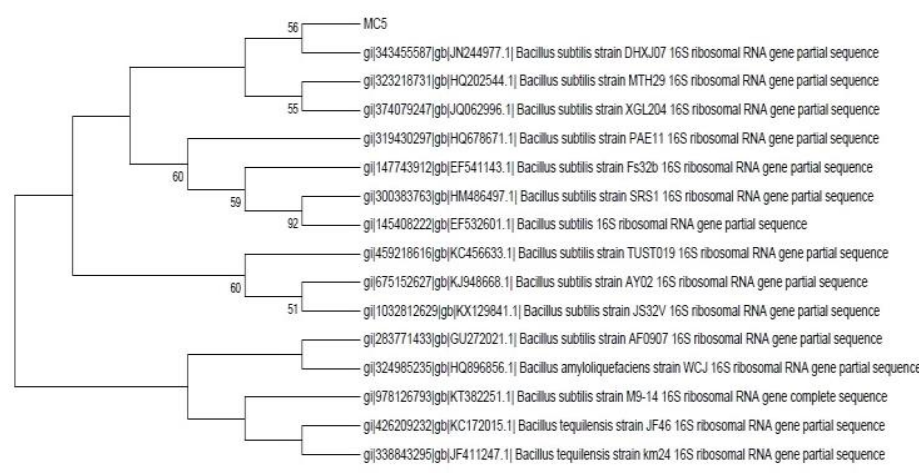

(c)

Figure 6 Phylogenetic analysis of the isolates based on 16S rDNA sequence analysis. (a) Phylogenetic tree of isolate MA5, (b) phylogenetic tree of isolate $\mathrm{MB5}$, and (c) phylogenetic tree of isolate MC5.

\section{DISCUSSION}

Metal polluted environment contains microorganisms which have adapted to toxic concentrations of heavy metal. Such a microbial population is resilient to metal toxicity by various mechanisms involving bioaccumulation and bioadsorbtion, oxidation and reduction, methylation and demethylation and extrusion of toxic ions by efflux systems (Bolton and Gorby, 1995). These microorganisms can potentially remove heavy metals from the polluted environment. Many bacterial species, both gram positive and gram negative, have been implicated in bioremediation studies. In the present study, three cadmium resistant bacteria were isolated from industrial soil samples which tolerated high concentrations of $\mathrm{Cd}^{+2}, \mathrm{~Pb}^{+2}, \mathrm{Ni}^{+2}, \mathrm{Cu}^{+2}$ and $\mathrm{Hg}^{+2}$. These isolates were also found to be resistant to many antibiotics. Since there is a documented association between metal resistance and antibiotic resistance and the genes conferring the same are thought to reside on a plasmid, all the three bacterial isolates were screened for the presence of plasmids and it was found that all the isolates harboured the plasmid. Many studies indicate a close association between the types and levels of metal contamination and specific patterns of antibiotic resistance. The mechanisms that underlie this co-selection process include coresistance and cross-resistance (Baker-Austin $\boldsymbol{e t}$ al., 2006). The selected isolates were found to be resistant to a range of heavy metals demonstrating that environmental bacteria may adapt to their ecological conditions and may have been selected for certain metal tolerance mechanisms. Such bacterial strains may be potential candidates for their simultaneous removal from wastes. Several studies on application of growing microbial cells for metal scavenging have been reported (Malik, 2004). Under lab conditions, these isolates were able to remove upto $70-78 \%$ cadmium. A slight difference in phenotypic characteristics was observed among three bacterial isolates, suggesting the presence of different species. The morphological characters and biochemical attributes of isolates MA5, MB5 and MC5 provide evidence to their resemblance with Bacillus genera. Further molecular characterization was done to confirm identification. The 16S-rDNA sequencing confirmed identification of MA5, MB5 and MC5 as Bacillus sp.263ZY1, Bacterium YC-LK-LKJ45 and Bacillus subtilis strain DHXJO, respectively.

Many studies have implicated Bacillus spp. in bioremediation of heavy metals Bacillus safensis strain was found to tolerate cadmium up to the concentration of $80 \mathrm{ppm}$ and the reduction and absorption of cadmium was $83.5,39 \%$ and 98.10 $92 \%$ at 40 and $60 \mathrm{ppm}$ of cadmium, respectively at pH 7. Khosro et al. (2011) used different Bacillus strains for the removal of heavy metals. The results revealed that maximum cadmium accumulation were $7.3 \mathrm{~mol} / \mathrm{g}$ biomass for B.licheniformis, $10.7 \mathrm{~mol} / \mathrm{g}$ biomass for B.cereus, $9.5 \mathrm{~mol} / \mathrm{g}$ biomass for $B$ subtilis and $7.2 \mathrm{~mol} / \mathrm{g}$ biomass for B. amyloliquefaciens. In another study, Bacillus subtilis isolated from industrial effluent soil showed maximum accumulation at $200 \mu \mathrm{g} / \mathrm{ml}$ and showed saturation above that concentration $(250$ $\mu \mathrm{g} / \mathrm{ml}$ ) (Gayathramma et al., 2013). Significant reduction of soluble Cd was observed during growth of plasmid-bearing Bacillus strain H9 and Pseudomonas strain H1 (Roane and Pepper, 2000).

The environmental contamination arising primarily from agricultural and industrial sources, as a result of the increase in population, industrial activities, and the modernization of agricultural practices, such as the increasingly widespread use of pesticides, resulting in an increase of the amount of effluents thrown into the air, water, and soil, and have consequences on food quality and human health which are very serious worldwide problems. Bacteria have been so continuously exposed to heavy metal contaminants of the environment that they have developed genetically determined resistance systems against heavy metal toxicity. Contaminated environments like those in the vicinity of industries or industrial dump grounds accumulate a heavy burden of toxic metal ions, organic wastes and antibiotics. A large number of bacterial isolates from these areas have depicted a pronounced capability of processing and resisting toxic industrial wastes. All the three bacteria isolated in this study show a high efficiency in removal of $\mathrm{Cd}$ from the medium. They accumulated a significant amount of $\mathrm{Cd}$ within 24h. These three strains were belong to Bacillus spp. Cadmium uptake is reported to be through an ATPase pump in Gram positive bacteria and by the action of proton-cation anti-porters in Gram negative bacteria (Nies and Silver1995). These capabilities of the selected strains make them suitable for bioremediation of contaminated environment.

\section{CONCLUSION}

The present investigation was designed to isolate cadmium resistant bacteria which possessed multiple resistances to various heavy metals and consequently could be used for the simultaneous removal of more than one heavy metal from contaminated environment. The capability of microbial strains to grow in the presence of heavy metals would be helpful in the waste water treatment. In the present study, bacterial isolates belonging to genera Bacillus, showing high degree of resistance to various heavy metals was isolated from soil. These strains were capable of removing upto $78 \%$ of cadmium, signifying that these Bacillus strains can be efficiently used for bioremediation and removal of cadmium present in polluted water with minimum cost and high efficiency.

\section{REFERENCES}

Baker-Austin, C., Wright, M.S, Stepanauskas, R. \& McArthur, J.V. (2006). Coselection of antibiotic and metal resistance. Trends Microbiology, 14(4), 176-182. Bolton, H. Jr. \& Gorby, Y.A. (1995). An overview of the bioremediation of inorganic contaminants. In: Hinchee, R.E., Means, J.L. \&Burris, D.R. (eds.) Bioremediation of Inorganics. Battelle Press, Ohio. 1-6.

Bruno, W. J., Socci, N. D. \& Halpern, A.L. (2000). Weighted neighbor joining: a likelihood-based approach to distance- based phylogeny reconstruction, Molecular Biolgy and Evolution,17,189-197.

Cameron, R.E. (1992). Guide to site and soil description for hazardous waste characterization. I, Metals. Environmental Protection Agency. EPA/600/491/029.

Chen, X.C., Wang, Y. P., Lin, Q., Shi, J.Y., Wu, W.X., \& Chen, Y.X. (2005) Biosorption of copper (II) and zinc (II) from aqueous solution by Pseudomonas putida CZ1. Colloids and Surfaces B: Biointerfaces, 46, 101 107.http://dx.org/10.1016/i.colsurfb.2005.10.003

De, J., Ramaiah, N., \& Vardanyan, L. (2008). Detoxification of toxic heavy metals by marine bacteria highly resistant to mercury. Marine Biotechnology, 10, 471-477. 
Gayathramma, K., Pavani, K.V., Singh, A. R. \& Deepti, S. (2013). Role of Bacillus subtilis in Bioremediation of heavy metals. International Journal of biological research, 6(1), 6-11.

Hu, H. (1998). Heavy metal poisoning. Chapter 397. In: Fauci, A.S., Braunwald, E., Isselbacher, K.J., Wilson, J.D., Martin, J.B., Kasper, D.L., Hauser, S.L., Longo, D.L. editors. Harrison's principles of Internal medicine. 14th ed. New York: McGraw-Hill. 2564-2569.

Khosro, I., Mohammad reza majid, K.P, \& Alireza, M., (2011). Bioremediation of toxic heavy metals pollutants by Bacillus spp. isolated from Guilan bay sediments, north of Iran, International Conference on Biotechnology and Environment Management (IPCBEE), $\quad 18, \quad 67-71$ http://dx.doi.org/10.6088/ijes.2013030500037

Kumar S., Stecher G. \& Tamura K. (2015). MEGA7: Molecular Evolutionary Genetics Analysis version 7.0 for bigger datasets.Molecular Biology and Evolution (submitted)

Malik, A. (2004). Metal bioremediation through growing cells. Environment International, 30, 261-278.

Malik, A. \& Jaiswal, R. (2000). Metal resistance in Pseudomonas strains isolated from soil treated with industrial wastewater. World Journal of Microbiology Biotechnology, 16, 177-182.http://dx.doi.org/10.1023/A:1008905902282

Meena, A. \& Rajagopal, C. (2004). Comparative studies on Adsorptive Removal of Chromium from Contaminated water using different Adsorbents. Indian Journal of Chemical Technology, 10, 72-78.

Nies, D.H. \& Silver, S.(1995). In efflux systems involved in bacterial metal resistances. Journal of Industrial Microbiology, 14(2), 186-199. http://dx.doi.org/10.1007/BF01569902

Raone, T.M. \& Pepper I.L. (2000). Microorganisms and Metal pollutants. In:

Maier, R.M., Pepper, I.L., Gerba, C.P.(eds). Environmental Microbiology Academic Press. San Diego, USA, 403-423.

Sambrook, J., Fritsch, E.F. \& Maniatis, T. (1989) Molecular Cloning-A Laboratory Manual. 2nd Edition, Cold Spring Harbor Laboratory Press, Cold Spring Harbor.

Saitou N. \& Nei M. (1987). The neighbor-joining method: A new method for reconstructing phylogenetic trees. Molecular Biology and Evolution 4:406-425.

Sinha, S. \& Mukharjee, S.K. (2009) Pseudomonas aeruginosa KUCD1, A Possible Candidate for Cadmium bioremediation. Brazilian Journal of Microbiology, 40, 655-662. $\quad$ http://dx.doi.org/10.1590/S1517.

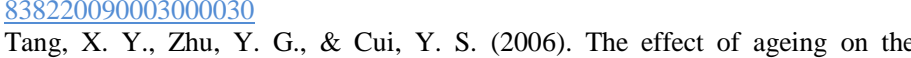
Bioaccessibility and Fractionation of Cadmium in some typical soils of China. Journal of Environmental International, 32, 682689.http://dx.doi.org/10.1016/j.envint.2006.03.003 